\title{
nature
}

\section{Taking a hard line on conflicts}

A clampdown on conflicts of interest at the US National Institutes of Health needn't stifle quality research at the agency and it might indicate the shape of things to come elsewhere.

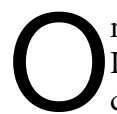
n 1 February, Elias Zerhouni, the director of the National Institutes of Health (NIH), announced new rules that are clearly intended to put an end to one of the more embarrassing episodes in the agency's recent history.

The rules put strict limits or outright bans on the outside activities of 18,000 NIH employees, most of them at the agency's main campus in Bethesda, Maryland. They were drawn up in response to a series of articles in the Los Angeles Times that spurred a congressional investigation into alleged abuses of the NIH's previous conflict-of-interest rules. Zerhouni says the rules have to be stringent, and that the agency must draw "a bright line" between unethical and ethical activities.

All the agency's employees will now be banned from doing paid or unpaid consulting for industry, healthcare providers, educational or non-profit institutes that receive NIH money, as well as for professional, trade or lobbying associations. Senior employees are banned from receiving many types of monetary gift, and from holding any stock in biotechnology, pharmaceutical and medical-device companies. Non-senior staff can only hold up to $\$ 15,000$ of such stock.

The new rules reverse those issued in 1995 by then NIH director Harold Varmus, which expressly permitted consulting activities as part of an effort to entice university scientists to join the agency. Some $\mathrm{NIH}$ staff are upset by the new restrictions, and many view them as an overreaction to abuses by a small number of scientists. Scientific societies are also expressing legitimate concerns about what the rules will mean for NIH scientists who want to serve on editorial boards, or take part in their professional development activities.

If Varmus's rules allowed too much outside commercial activity,
Zerhouni's seem to allow too little. Clearly, his back was up against the wall. The conflict-of-interest scandal first broke in December 2003, and he proposed a softer response. But as 2004 wore on, embarrassing revelations piled up, and it became clear that about 100 scientists had failed to inform the NIH of their activities, and a few were engaged in more egregious conduct. Publicity over the latter forced Zerhouni to take what he admits is "drastic action".

The restrictions will make it tougher for the NIH to recruit certain types of researcher. This may be especially true given other knocks to morale in recent years, such as the security measures that give the NIH the feel of a 'gated community' in the aftermath of the terrorist attacks of 11 September 2001. But a great many loyal NIH researchers are there not for the money, but for the chance to work at the largest, most diverse and best-equipped biomedical research centre in the world. It would be foolhardy to regard restrictions on outside commercial activity as the death knell for the agency's ability to attract top talent.

Indeed, the clampdown at the NIH could well foreshadow similar action outside the agency. Momentum is building for an examination of conflicts of interest on the campuses of research universities and academic medical centres around the United States. Last week, Zerhouni himself raised the issue: "In addition to preserving the trust of the public in a federal agency at the NIH, we need to preserve the trust of the public in the research enterprise in general." He added that there is a need to encourage a re-evaluation of the conflict-ofinterest policies at academic campuses. With the nation's attention now drawn to the issue, scientists and institutions everywhere should be sure that their own houses are fully in order.

\section{Not so fast}

\section{Anyone thinking of collaborations with emerging biomedical powers should test the ethical waters before jumping in.}

A UK government 'Global Watch Mission' returned from a twoweek trip to China, Singapore and South Korea in September with a glowing report on the state of stem-cell research there. A press release announcing the report, released last month, noted that these countries were "bringing their ethical standards more in line with the UK model" and suggested that "the quality and international standing of UK-based stem cell organisations would provide an ideal opportunity for UK-Far East collaboration".

All set then. But is this just wishful thinking?

Each of these countries recently put national regulatory frameworks in place, with South Korea's coming into effect just last month (see Nature 433, 186; 2005). But are they observed and enforced?

Members of the UK party visited some top-class laboratories in China (www.globalwatchonline.com/missions/tmsmrep.aspx). But can their observations be generalized to the whole country? After noting that in China there is "much less resistance than would be met in the West to pursuing experimental therapies into clinical practice", the summary follows: "This is not to imply that clinical research is either unethical or unregulated."

Nor should it be taken as a sign that all is well. There are stories of
Chinese trials that fail to get informed consent and take advantage of desperate patients. China has regulations, but how well they are observed across the country is another question - indeed, many of those trials are said to involve local government officials. We have only to remember the blood-collection scandals in which uncounted numbers of Chinese were infected with HIV to know what local governments can do without anyone noticing - until it all blows up.

Anyone considering collaborations in a country with a questionable record on ethical regulation should snoop around first. The UK mission in China encountered repeated obstacles to inspecting informed-consent forms. The South Korean researchers who carried out last year's famed cloning experiments have also consistently refused to show the types of forms they used (Nature 429, 3; 2004). These are warning signs.

The new regulations may snap researchers into shape in the same way that China's political measures ensure conformity. This strictness would then, it is hoped, extend to international collaborations. But the odds are that some researchers will take advantage of lax enforcement in China or other countries. Some will get away with it. Others might sink their careers in a project gone awry. 